Abstracta Iranica Iranica

Revue bibliographique pour le domaine irano-aryen

Volume 27 | 2006

Comptes rendus des publications de 2004

\title{
« Historiography. iii. Early Islamic Period ». EIr, XII, (2004), pp. 330-348.
}

\section{David Durand-Guédy}

\section{OpenEdition}

1 Journals

\section{Édition électronique}

URL : http://journals.openedition.org/abstractairanica/5901

DOI : 10.4000/abstractairanica.5901

ISSN : 1961-960X

Éditeur :

CNRS (UMR 7528 Mondes iraniens et indiens), Éditions de l'IFRI

\section{Édition imprimée}

Date de publication : 15 mai 2006

ISSN : 0240-8910

\section{Référence électronique}

David Durand-Guédy, « « Historiography. iii. Early Islamic Period ». Elr, XII, (2004), pp. 330-348. », Abstracta Iranica [En ligne], Volume 27 | 2006, document 149, mis en ligne le 02 janvier 2007, consulté le 25 septembre 2020. URL : http://journals.openedition.org/abstractairanica/5901 ; DOI : https:// doi.org/10.4000/abstractairanica.5901

Ce document a été généré automatiquement le 25 septembre 2020.

Tous droits réservés 


\title{
« Historiography. iii. Early Islamic Period ». EIr, XII, (2004), pp. 330-348.
}

\author{
David Durand-Guédy
}

Cet article présente les principales sources historiques de l'Iran pré-mongol. Ce corpus, déjà vaste, ne représente pourtant qu'une partie des sources permettant de travailler sur l'Iran pré-mongol, dans la mesure où l'historien devra aussi aller chercher ses informations ailleurs que dans les seuls auteurs iraniens, les seules sources prémongoles et les textes purement historiques (l'importance des sources littéraires n'est plus à démontrer). Les sources historiques, jugées "généralement de qualité médiocre » (p. 343a) par l'A., sont présentées selon quatre périodes chronologiques: «the formative period», peu documentée ; "the high califate», dominée par l'œuvre de Tabari ; "the era of the regional dyansties », partagé entre les domaines oriental (Bayhaqi) et occidental (Miskawayh) : enfin « the late islamic period » qui correspond à la période saljuqide et au demi-siècle qui suivit - l'A. a inclus dans cette dernière section les histoires locales. La troisième période $\left(10^{\mathrm{e}}-11^{\mathrm{e}} \mathrm{s}\right.$.), que Daniel connaît le mieux (cf. not. son article important sur Bal'ami, JRAS, 1990), est celle traitée la plus en détail. Cet article est une synthèse intelligente, claire et à la fois érudite de la masse des publications sur le sujet (la bibliographie couvre 6 pages). Pour l'historien de l'Iran, il est infiniment plus cohérent que les notices récemment publiés dans l'Encyclopédie de l'Islam, où étaient artificiellement distinguées l'historiographie du monde arabe de l'historiographie persane (cf. Abs. Ir. 26, $\mathrm{n}^{\circ} 138$ et 142). 
INDEX

Thèmes : 4.1. Histoire médiévale

nompropre Bayhaqi, Miskawayh, Bal'ami

Keywords : Tabari

\section{AUTEURS}

DAVID DURAND-GUÉDY

IFRI - Téhéran 